\title{
Protein-to-Protein Interactions: Criteria Defining the Assembly of the Enamel Organic Matrix
}

\author{
M.L. Paine ${ }^{1 *}$, P.H. Krebsbach ${ }^{2}$, L.S. Chen ${ }^{1}$, C.T. Paine', Y. Yamada ${ }^{3}$, D. Deutsch ${ }^{4}$, and M.L. Snead ${ }^{1}$ \\ ${ }^{1}$ University of Southern California, School of Dentistry, Center for Craniofacial Molecular Biology, 2250 Alcazar Street, CSA Room 142, Los \\ Angeles, California 90033; ${ }^{2}$ The University of Michigan, School of Dentistry, Room 4207, Ann Arbor, Michigan 48109-1078; ${ }^{3}$ Laboratory of \\ Craniofacial Developmental Biology and Regeneration, National Institute of Dental Research, National Institutes of Health, Bethesda, \\ Maryland 20892; ' Dental Research Unit, Hebrew University, Hadassah Faculty of Dental Medicine, Jerusalem, Israel; ${ }^{*}$ to whom \\ correspondence should be addressed
}

\begin{abstract}
Enamel crystallites form in a protein matrix located proximal to the ameloblast cell layer. This unique organic extracellular matrix is constructed from structural protein components biosynthesized and secreted by ameloblasts. To date, three distinct classes of enamel matrix proteins have been cloned. These are the amelogenins, tuftelin, and ameloblastin, with recent data implicating ameloblastin gene expression during cementogenesis. The organic enamel extracellular matrix undergoes assembly to provide a three-dimensional array of protein domains that carry out the physiologic function of guiding enamel hydroxyapatite crystallite formation. Using the yeast twohybrid system, we have surveyed these three known enamel gene products for their ability to direct self-assembly. We measured the capacity of the enamel gene products to direct protein-to-protein interactions, a characteristic of enamel proteins predicated to be required for self-assembly. We provide additional evidence for the self-assembly nature of amelogenin and tuftelin. Ameloblastin self-assembly could not be demonstrated, nor were protein-to-protein interactions observed between ameloblastin and either amelogenin or tuftelin. Within the limits of the yeast twohybrid assay, these findings constrain the emerging model of enamel matrix assembly by helping to define the limits of enamel matrix protein-protein interactions that are believed to guide enamel mineral crystallite formation.
\end{abstract}

Key words: amelin, ameloblastin, amelogenin, biomineralization, enamel, enamelin, protein matrix assembly, sheathlin, tooth development, tuftelin, yeast two-hybrid system, protein interactions.

\section{Introduction}

Understanding the functional role of enamel proteins during enamel biomineralization is a long-sought goal (Traub et al., 1984). Enamel forms entirely extracellularly, with the removal of enamel proteins coinciding with their replacement by carbonated hydroxyapatite crystallites. The assembly of the enamel organic matrix, its disassembly by proteases, and the growth of the mineral phase at the expense of the organic phase imply that enamel formation is an extremely complex biological phenomenon which operates as a consequence of tightly regulated and orchestrated control mechanisms.

To date, an essential physiologic role for an enamel protein during enamel formation has been demonstrated only for amelogenin. In the case of amelogenin, humans affected by an inherited enamel defect known as amelogenesis imperfecta exhibit a defect in the amelogenin gene locus located on the X-chromosome (Lau et al., 1989). This defect results in reduced or eliminated amelogenin expression, thus providing a genetic link to amelogenin as an essential component of the enamel matrix (Aldred et al., 1992). Similar defects in enamel formation have also been experimentally shown in animals when amelogenin protein levels were dramatically reduced when the amelogenin messenger RNA was targeted for cleavage by means of hammerhead ribozymes (Lyngstadaas et al., 1995), thus corroborating a required role for amelogenin proteins during matrix assembly.

Ameloblastin (also known as amelin or sheathlin; Fong et al., 1996; Krebsbach et al., 1996; Snead 1996; Hu et al., 1997) is an extracellular protein that is expressed at high levels in secretory and post-secretory ameloblasts (Fong et al., 1996). A precise role for ameloblastin during enamel organic matrix formation is not yet known. Recent studies by MacDougall and colleagues have implied an essential role for ameloblastin during enamel formation by their genemapping experiments which place the ameloblastin gene locus in the critical region of autosomal-dominant forms of amelogenesis imperfecta (MacDougall et al., 1997). In situ 
Table 1. Oligonucleotides used to construct GAL4 hybrid plasmids containing the enamel matrix proteins

amelogenin forward primer (Bam $\mathrm{HI}$ )

amelogenin reverse primer (Sac I)

tuftelin forward primer (Bam HI)

tuftelin reverse primer (Sac I)

ameloblastin forward primer (Sal I)

ameloblastin forward primer (Bgl II)

ameloblastin reverse primer (Aat II)

\author{
TTCGGATCCCT.ATGCCCCTACCACCT ${ }^{a}$ \\ TTAGAGCTCTTAATCCACTTCTTC \\ TTCGGATCCCC.ATGGTGTCCAGCCACTCA \\ TTAGAGCTCTAGTCCTCTGTCTGCC \\ GAGGTCGACA.ATGTCAGCATCTAAG \\ TTCAGATCTCC.GTGCCGGCATTTCCT \\ TAAGACGTCAGGGCTCTTGGAA
}

a Restriction sites are underlined, and a period indicates the beginning of the coding sequence.

hybridization experiments also localize ameloblastin messenger RNA to epithelial cells adjacent to the surface of newly deposited dentin along the root stock and to cells embedded in cellular cementum (Fong et al., 1996). Several decades ago, Slavkin and Boyde (1974) proposed an epithelial origin of cementum, and with the cloning of ameloblastin, their prediction of epithelial gene products within the cementum has been substantiated. In addition to its role in enamel formation, the identification of ameloblastin expression during cementogenesis suggests that it may also be a candidate gene for inherited forms of disturbances in cementum differentiation.

To date, an essential role for tuftelin in enamel organic matrix formation has not been conclusively proven. The tuftelin gene is highly conserved throughout vertebrate evolution (Deutsch et al., 1991a). Tuftelin remains strongly implicated in the formation of normal enamel and in the pathogenesis of enamel defects by virtue of the physical and chemical characteristics of this acidic macromolecule and its potential role in initiating crystallite formation (Deutsch $e t$ al., 1991b; Traub et al., 1984).

Enamel forms entirely extracellularly, implying that the enamel protein constituents must be able to assemble into a competent organic protein matrix that directs its replacement by the inorganic mineral phase. The unique physical and chemical properties of the enamel extracellular matrix have long been known (Nikiforuk and Simmons, 1965; Mechanic et al., 1967; Limeback and Simic, 1990). Recently available molecular biology techniques have now provided experimental leverage for their elucidation. For example, experimental support for the self-assembly of enamel proteins comes from in vitro experiments in which highly purified bacterially expressed M180 amelogenin was shown to assemble into structures resembling nanospheres (Fincham et al., 1994). Corroboration for the concept of in vitro-generated nanospheres has come from the observation that nanosphere structures can also be observed during in vivo enamel formation (Moradian-Oldak et al., 1994a,b; Fincham et al., 1995).

In 1989, Fields and Song published a method, referred to as the yeast two-hybrid system, to examine protein-protein interactions in eucaryotic yeast hosts. This method uses $\beta$ galactosidase activity to indicate the avidity of interaction between two proteins, and has been widely used to identify protein-protein interactions occurring within either the cell nucleus or the cell cytoplasm. We reasoned that the twohybrid assay might turn out to be a valuable tool to study extracellular matrix assembly properties for the enamel proteins. Our findings relate enamel-protein assembly properties to likely roles for amelogenin, tuftelin, and ameloblastin during enamel formation. These findings do not provide specific functions for any of the known enamel proteins, but rather provide in vitro evidence that there are limitations to the protein-protein interactions that define the assembly of the enamel extracellular matrix. The results of our present study suggest that the capacity of amelogenin and tuftelin to direct their own extracellular assembly during enamel biomineralization is an important step in producing a competent organic matrix that directs its replacement by the mineral phase.

\section{Materials and methods}

\section{Plasmid construction}

A complete explanation of the yeast two-hybrid assay (Fields and Song, 1989) and the mother-plasmids used (PPC97 and pPC86) in this study (Chevray and Nathans, 1992) has been published elsewhere (Paine and Snead, 1997). Briefly, pPC97 is the GAL4 binding-domain-containing plasmid, and pPC86 is the GAL4 activating-domain plasmid. The polylinkers of pPC97 and PPC 86 are identical. The entire coding region (as published) of amelogenin and an isoform of amelogenin, the leucine-rich amelogenin protein or LRAP (Lau et al., 1992), or tuftelin (Deutsch et al., 1991b) or ameloblastin (Krebsbach et al., 1996) were PCR amplified from a plasmid template by standard methods and cloned into plasmids PPC97 and pPC86 (Chevray and Nathans, 1992), as described elsewhere (Sambrook et al., 1989; Mosteller et al., 1995; Paine et al., 1996; Paine and Snead, 1997). Primers for amelogenin amplify the cDNA corresponding to amino acids 1 through 180 (M180) and amino acids 1 through 59 (LRAP). Primers for tuftelin amplify the cDNA corresponding to amino acids 1 through 389 , and primers for ameloblastin amplify the cDNA corresponding to amino acids 1 through 422 (signal peptide included) or amino acids 27 through 422 (signal peptide excluded). The pre-pro leader of amelogenin (Lau et al., 1992) has been omitted for this study (Paine and Snead, 1997), while the signal peptide sequence of ameloblastin (amino acids 1 through 26) has been included in this study. Oligonucleotides used for PCR contained restriction sites to allow for efficient, in-frame sub-cloning of the generated DNA (Table 1). We obtained DNA across cloning sites of each plasmid to confirm the correct orientation and framing of the cDNA insert. Amelogenin, LRAP, and tuftelin DNA were 
Table 2. Protein-protein interactions as detected by the filter assay for $\beta$-galactosidase activity.

\begin{tabular}{|c|c|c|c|c|}
\hline \multirow{2}{*}{$\begin{array}{l}\text { GAL DNA Binding } \\
\text { Domain Fusion } \\
\text { amelogenin }\end{array}$} & \multirow{2}{*}{$\begin{array}{l}\text { GAL4 Activation } \\
\text { Domain Fusion } \\
\text { amelogenin }\end{array}$} & \multicolumn{2}{|c|}{$\begin{array}{c}\text { Interaction } \\
\text { (relative strength) }\end{array}$} & \multirow{2}{*}{$\frac{\text { Reference }}{\text { Paine and Snead, } 1997}$} \\
\hline & & + & $(1)^{\mathrm{a}}$ & \\
\hline amelogenin & LRAP & weak & $(0.13 \pm 0.02)$ & Paine and Snead, 1997 \\
\hline tuftelin & tuftelin & ++ & $(9.9 \pm 2.51)$ & Paine et al., 1997 \\
\hline ameloblastin $^{b}$ & ameloblastin $^{\mathrm{b}}$ & - & $(0.0)$ & \\
\hline ameloblastin $^{\mathrm{b}}$ & ameloblastin $^{c}$ & - & $(0.0)$ & \\
\hline amelogenin & tuftelin & - & $(0.0)$ & Paine and Snead, 1997 \\
\hline ameloblastin $^{\mathrm{b}}$ & amelogenin & - & $(0.0)$ & \\
\hline ameloblastin $^{\mathrm{b}}$ & tuftelin & - & $(0.0)$ & \\
\hline p53 & SV40 large $T$-antigen & + & $(0.66 \pm 0.17)$ & $\begin{array}{l}\text { Paine and Snead, } 1997 \\
\text { Li and Fields, } 1993\end{array}$ \\
\hline $\mathrm{H}$-ras & $\mathrm{CDC} 25$ & +++ & $(>16)$ & Mosteller et al., 1994 \\
\hline
\end{tabular}

a Relative strength of interaction ( \pm standard error) indicated in parentheses as determined by the liquid culture assay for $\beta$-galactosidase activity (quantitative data).

b Ameloblastin epitopes generated with the leader signal peptide.

c Ameloblastin epitopes generated without the leader signal peptide.

cloned into the Bgl II/Sac I site of each hybrid-vector, and the ameloblastin DNA was cloned into the Sal I/Aat II site (signal peptide included) of each vector and the Bgl II/Aat II site (signal peptide excluded) of the pPC86 vector. Positive hybrid plasmids for $\mathrm{p} 53$ and SV40 large T-antigen were purchased from Stratagene (La Jolla, CA, USA), and hybrid plasmids for $\mathrm{H}$-ras and CDC25 were provided by Drs. D. Broek and R. Mosteller (University of Southern California).

\section{$\beta$-galactosidase activity}

The filter assay was used to assess $\beta$-galactosidase activity, a parameter directly reflecting the strength of hybrid-protein interactions. Double plasmid transformations were made into the yeast strain PCY2. Doubly transformed yeast colonies were established, and three separate colonies were streaked onto filter paper (filter assay) and allowed to grow for 2 days on selection medium. We permeabilized yeasts by freezing the yeast-impregnated filter in liquid nitrogen, then thawing it at room temperature. The filter was placed on a second filter presoaked in a $0.1-\mathrm{M}$ phosphate buffer $(\mathrm{pH} 7.0)$ containing 300 $\mu \mathrm{g} / \mathrm{mL}$ 5-bromo-4-chloro-3-indolyl- $\beta$-D-galactopyranoside (Xgal), and $0.27 \% \beta$-mercaptoethanol. Filters were left for $48 \mathrm{hrs}$ to develop a blue color, this color change being the indication of a positive interaction.

In addition, quantitative data relating the relative strengths of hybrid-protein interactions were obtained by means of the liquid culture (ONPG) assay (Sambrook et al., 1989; Ausubel et al., 1995). Using the liquid culture assay, we examined all hybrid combinations of constructs concurrently, and repeated the experiment in its entirety on three separate occasions. On each occasion, spectrophotometric measurements were quantitated against the full-length, processed amelogenin construct interacting with itself (Table 2). The mean and standard error were calculated for each positive doubletransformant combination (Table 2), except for the reading for
$\mathrm{H}$-ras interacting with $\mathrm{CDC} 25$, which showed such an intense color that it was difficult to get an accurate reading.

\section{Western detection of proteins}

To ascertain if negative interactions might be due solely to the absence of target proteins, we analyzed the ameloblastin constructs for their ability to express the fusion protein. Detailed methods for protein detection were used as published (Simmer et al., 1994). In brief, total protein was recovered from yeast cells transformed with the nominated plasmid ( $\mathrm{Li}$ and Fields, 1993), and equivalent amounts of protein for each sample were loaded and resolved to size by means of $10 \%$ SDS-PAGE. The gel was electrotransferred to polyvinylidene fluoride (PVDF) membrane (Millipore, Bedford, MA, USA), blocked extensively (with $1 \%$ albumin and $1 \%$ goat serum), and ameloblastin epitopes detected by use of a rabbit polyclonal antibody raised against recombinant ameloblastin at a dilution of 1:200 at room temperature overnight.

\section{Results}

Results for interactions among the three cloned enamel matrix proteins-amelogenin (and LRAP), tuftelin, and ameloblastin-are provided in Table 2 , along with positive control combinations. The data listed in Table 2 relate the relative strengths of interactions (when compared with intact amelogenin interacting with itself, larger numbers indicating higher avidity) as recorded by the liquid culture assay for $\beta$-galactosidase activity (Sambrook et al., 1989; $\mathrm{Li}$ and Fields, 1993). Positive controls were the tumor suppressor protein p53 co-transformed with the SV40 large T-antigen (Lane and Crawford, 1979; Li and Fields, 1993), and H-ras (wild type) co-transformed with the CDC25 protein of Saccharomyces cerevisiae (Mosteller et al., 1994, 1995). Negative controls involve each of the enamel proteinhybrid constructs co-transformed with either PPC86 (for the pPC97 hybrids) or pPC97 (for the pPC86 hybrids). All negative control combinations had no ascertainable $\beta$-galactosidase activity as measured by the liquid culture assay.

The yeast two-hybrid assay was also performed on a filter supporting three colonies of each combination of test constructs, and results obtained were consistent with the liquid culture assay. A blue color developed within the first hour for the $\mathrm{H}$-ras construct co-transformed with the CDC25 protein construct, and over a two-hour period for the tuftelin construct co-transformed with itself. Blue developed for the M180 amelogenin construct co-transformed with itself and for p53 construct co-transformed with SV40 large T-antigen construct over an approximate eight- to 10-hour period. A very pale blue for the M180 amelogenin construct 
co-transformed with the LRAP construct was present after 24 hrs. No blue developed over the following 24 hrs for interactions involving ameloblastin, or amelogenin cotransformed with tuftelin, and these combinations have been recorded as negative results. Negative control combinations showed no blue development over the $48 \mathrm{hrs}$.

Western detection of an ameloblastin epitope was achieved for the ameloblastin fusion protein produced in plasmid pPC97 (which included the signal peptide sequence) (Fig. 1, lane 4, and Fig. 2, lanes 2 and 4). Western analysis failed to show a product for the ameloblastin fusion protein (which included the signal peptide) subcloned into the PPC86 plasmid (Fig. 1, lane 3), and for this reason, a second ameloblastin-containing plasmid was prepared which did not include the signal peptide sequence. Failure to detect a hybrid-protein product in yeast has previously been observed (Bartel et al., 1993; Hannon and Beach, 1994). Failure to identify the hybrid-protein does not necessarily mean that the hybrid-ameloblastin gene product is not present. To ensure that the observed failure of ameloblastin to self-assembly and its failure to interact with either amelogenin or tuftelin were due to an intrinsic property of ameloblastin (and not due to an unstable hybrid-protein), we performed ameloblastin assembly interactions using only those constructs that did produce an identifiable hybrid product by Western analysis. Western detection of an ameloblastin epitope was achieved for the second ameloblastin fusion protein produced in plasmid pPC86 (Fig. 2, lanes 3 and 4). The ameloblastin construct in the PPC97 vector (including the leader sequence) was used to test for interactions with either amelogenin or tuftelin. Plasmid constructs producing epitopes of either M180 amelogenin, LRAP, or tuftelin interacted with at least one of the other plasmid constructs, and for this reason, stability of these hybrid-proteins within the yeast nucleoplasm has been assumed.

\section{Discussion}

Tooth enamel is a well-known example of protein-matrixmediated biomineralization. It has long been pursued as a useful model because of its relative simplicity at the cellular and protein levels when compared with the complexities of bone or dentin. Predominant proteins within the organic enamel matrix are the amelogenins and the enamelins, of which tuftelin is the only enamelin family member cloned. Amelogenin, tuftelin, and ameloblastin proteins are expressed exclusively by cells of the inner enamel organ and secreted into the developing enamel extracellular matrix. The genetic disease amelogenesis imperfecta has been mapped to the amelogenin gene locus in a number of families (Lagerström et al., 1991; Aldred et al., 1992; Lagerström-Fermer et al., 1995). The finding that defects in the amelogenin locus result in enamel matrix assembly defects may not be surprising, since the amino-terminal and the carboxyl-terminal peptide regions of amelogenin have been recently shown to interact with one another to enable amelogenin self-assembly to occur (Paine and Snead, 1997). The data identifying selfassembly properties for amelogenin also support both the in vitro and in vivo observations that amelogenins assemble into nanosphere structures composed of hundreds of

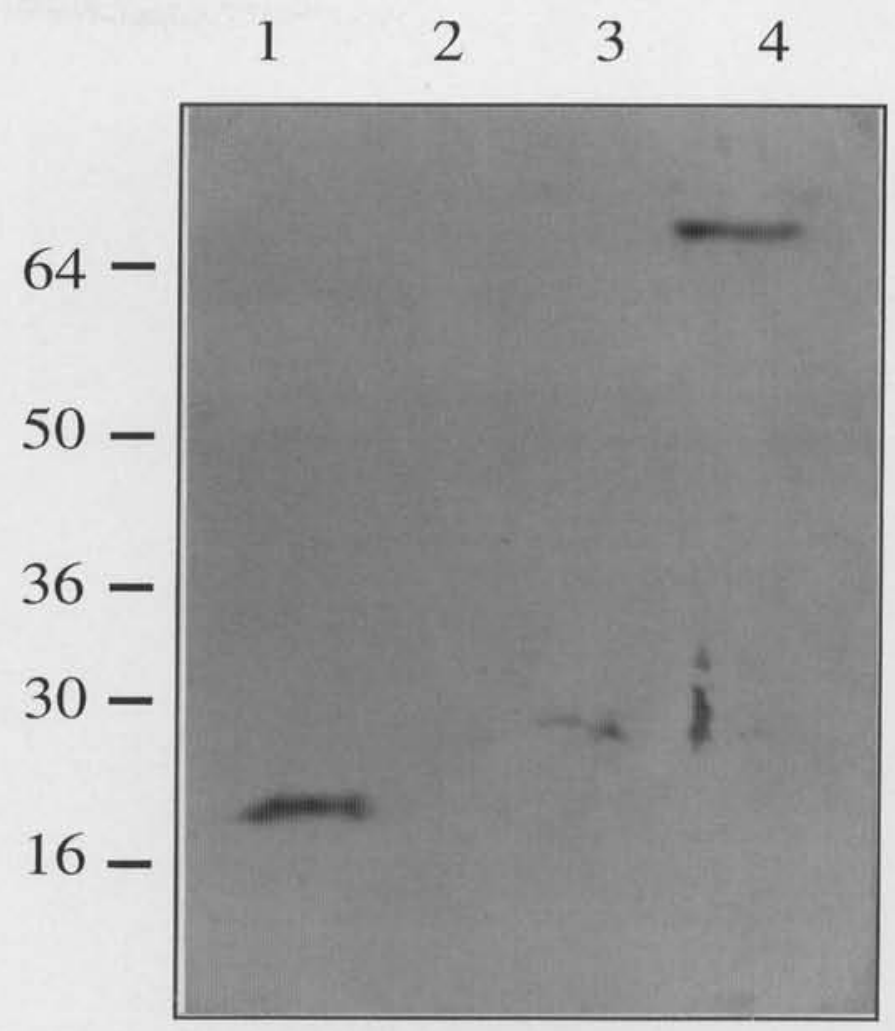

Figure 1. Western blot detection of ameloblastin epitopes. Size markers are in $\mathrm{kDa}$. Lane 1 , recombinant ameloblastin; lane 2, protein from yeast strain PCY2, acting as a negative control; lane 3, protein from yeast transformed with the GAL4 activating-domain vector ( $\mathrm{pPC} 86$ ) containing ameloblastin (with the signal peptide); and lane 4 , protein from yeast transformed with the GAL4 bindingdomain vector ( $\mathrm{PPC} 97$ ) containing ameloblastin (with the signal peptide). Recombinant ameloblastin produces a hybrid protein of $19 \mathrm{kDa}$, and the ameloblastin-containing GAL4 binding-domain vector produces a ameloblastin-hybrid protein of 574 amino acids.

amelogenin molecules (Fincham et al., 1995).

Further elaboration of the self-assembly properties of the enamel extracellular matrix has been recently identified for tuftelin (Deutsch et al., 1997; Paine et al., 1996). Tuftelin is a member of the anionic family of proteins known as the enamelins, and is most likely similar to the archetypal anionic proteins found ubiquitously among various biomineralizing schemas (Lowenstam and Weiner, 1989; Mann, 1993). Tuftelin has recently been shown to possess a domain enriched in acidic residues and a self-assembly domain, each located at opposite ends of the protein backbone, suggesting that spatial constraints on the tuftelin molecule may contribute to its ability to interact with enamel crystallites (Paine et al., 1996).

The recent cloning of ameloblastin (Cerny et al., 1996; Fong et al., 1996; Krebsbach et al., 1996; Lee et al., 1996; Hu et al., 1997) has introduced a third class of ameloblast-specific proteins. The nature of these proteins is the subject of intense interest and study. While amelogenin and tuftelin appear to be restricted in their expression to ameloblasts engaged in forming enamel, ameloblastin is expressed by ameloblasts during amelogenesis, as well as by cells of Hertwig's epithelial root sheath (Fong et al., 1996; Lee et al., 


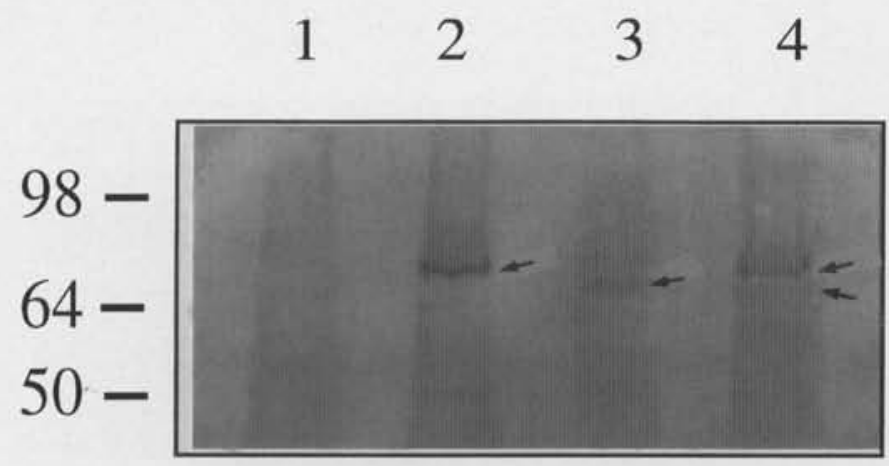

Figure 2. Western blot detection of ameloblastin epitopes. An arrow indicates the bands corresponding to GAL4 ameloblastin hybrid proteins. Size markers are in $\mathrm{kDa}$. Lane 1, protein from yeast strain $\mathrm{PCY} 2$, acting as a negative control; lane 2, protein from yeast transformed with the GAL4 binding-domain vector (pPC97) containing ameloblastin (with the signal peptide); lane 3, protein from yeast transformed with the GAL4 activating-domain vector (pPC86) containing ameloblastin (without the signal peptide); and lane 4, protein from yeast co-transformed with vectors as described for lanes 2 and 3 . The expected size in lane 2 corresponds to a product of 574 amino acids, and the expected size in lane 3 corresponds to a product of 520 amino acids. Lane 4 contains both the 574 - and 520-amino-acid products.

1996) during cementogenesis. This spatial pattern of expression suggests that the ameloblastin protein participates in the genesis of both tissue types (Fong et al., 1996; Lee et al., 1996). The immunodetection pattern for ameloblastin indicates that it is found at the interface between Tomes' process of the ameloblast (the ameloblast cytoplasmic extension involved with enamel protein secretion) and the newly secreted enamel organic matrix, but does not appear to extend into the recently secreted and as-yet-unmineralized enamel organic matrix (Fong et al., 1996; Krebsbach et al., 1996; Lee et al., 1996). An anchoring function between the ameloblasts and the enamel matrix has been suggested for ameloblastin based on this pattern of protein accumulation (Krebsbach et al., 1996). The data obtained in the present study suggest that the role of ameloblastin is likely to be distinct from that of both the enamelins and the amelogenins. An anchoring rather than a structural role is consistent with the continued expression of ameloblastins by cells of Hertwig's epithelial root sheath during the process of cementogenesis (Fong et al., 1996; Krebsbach et al., 1996; Lee et al., 1996). While a specific function for ameloblastin in cementogenesis is yet to be proven, MacDougall and colleagues (MacDougall et al., 1997) have shown that ameloblastin is a candidate gene for the autosomal form of the hereditary disease amelogenesis imperfecta in at least one affected family by placing the ameloblastin locus in the critical genetic area for the enamel defects. These investigators are currently assessing the status of cementum in these families (personal communication).

That the enamel organic matrix assembles in the extracellular space implies that the proteins themselves contain all the information required for assembly. Like other extracellular matrices, it is likely that assembly is dependent on protein motifs and the three-dimensional distribution of the proteins within the ordered whole of the matrix.
Deciphering the "code" that directs assembly of the enamel organic matrix may permit the construction of designed material that will mimic the function of the naturally occurring matrix, thus providing new avenues for the creation of restorative materials or regenerating matrices. A remarkable aspect of the enamel matrix is that the protein motifs comprising the self-assembly domains of both amelogenin and tuftelin do not appear to exhibit any affinity for one another (Paine et al., 1996; Paine and Snead, 1997). The apparent absence of amelogenin-to-tuftelin interaction (in the yeast two-hybrid assay) suggests either that a yet-tobe-identified "bridge" protein links amelogenin with tuftelin, or that these two proteins exert their influence on the forming crystallites without either the benefit of or interference from each other. This "two-phase" system for amelogenin and tuftelin bio-activity appears to be uninfluenced by ameloblastin. The finding of both proteinprotein interactions and protein-protein non-interactions among enamel proteins suggests that certain constraints act upon the enamel organic matrix during self-assembly. Amelogenin and enamelin proteins have been identified within the same secretory vesicle by means of highresolution immunodetection (Sasaki et al., 1997), suggesting an intimate relationship for these two proteins within the enamel organic matrix. The absence of an apparent interaction between amelogenin and enamelin protein may permit them to be co-secreted in one vesicle without the possibility of premature assembly of one with the other. The regulated formation of hydroxyapatite crystallites in mammalian enamel has been attributed to specific amelogenin-amelogenin interactions, amelogenin-crystallite interactions, and/or tuftelin-crystallite interactions. The enamelins, because of their physical and chemical properties, have been suggested to act as nucleation sites for crystallites during enamel biomineralization (Traub et al., 1984). Purified amelogenin protein can direct mineral deposition to the ends of hydroxyapatite seed crystals (Doi et al., 1984), suggesting a role for amelogenin in crystallite growth. The enamel protein matrix is transitory, being progressively removed with advancing mineral content (Moradian-Oldak et al., 1994b). Ultimately, this enamel protein matrix provides the critical interface between the organic and inorganic components, directing crystallite initiation, propagation, and termination.

Previously, it was shown that amelogenin and tuftelin will self-assemble (Fincham et al., 1994, 1995; Paine et al., 1996; Paine and Snead, 1997). The study presented here shows the failure of ameloblastin to self-assemble. Furthermore, we were unable to show protein-protein interactions between dissimilar enamel matrix proteins, indicating that the yeast two-hybrid system is a useful tool for the study of enamel matrix-protein interactions that lead to matrix assembly. Further applications of the yeast system would include the screening of cDNA expression libraries made from the developing mouse dentition in an attempt to clone additional genes involved in enamel matrix assembly. This strategy may result in the cloning of proteins with a capacity to interact directly by forming a "bridge" with any one of the known enamel matrix proteins. Additional light may be shed on the continuing enigma of vertebrate enamel bio- 
mineralization when new proteins are identified by means of the yeast two-hybrid assay, and their physiologic role may be more clearly identified through the creation of genetically engineered mice expressing either a "gain-offunction" or a "loss-of-function" mutation in the proteins that direct assembly.

Bashir and colleagues (Bashir et al., 1998) have recently reported a variation in genomic bovine tuftelin DNA sequence from that described by Deutsch (Deutsch et al., 1991b; discussion of Bashir et al., 1998). These investigators report a tuftelin protein lacking the 45 amino-acid residues at the carboxyl end as reported by Deutsch (Deutsch et al., 1991b); Bashir's tuftelin also has a different predicted aminoacid sequence after residue 297 . The sequence variation may represent a strain difference or a polymorphism in the sources of DNA used but suggests the possibility that there may be more than one carboxyl-terminal amino-acid sequence for the bovine tuftelins. The lack of the carboxylterminal 45 amino-acid residues should have negligible effect on tuftelin self-assembly, since these residues appear to play no role in mediating tuftelin-tuftelin interaction (Paine et al., 1996). However, a different protein sequence after residue 297 may have some impact on the ability of tuftelin to self-assemble (Paine et al, 1996).

\section{Acknowledgments}

Plasmids PPC97 and pPC86 and yeast strain PCY2 were kindly supplied by Pierre Chevray and Daniel Nathans. The authors thank Ya-Ping Lei and Benton Yoshida for their help thoughout this study. This work was supported by Grant numbers DE 06988, DE 08678, and DE 11704 from the NIDR.

\section{References}

Ausubel FM, Brent R, Kingston RE, Moore DD, Seidman JG, Smith JA, et al., editors (1995). Current protocols in molecular biology. New York: Wiley, p. 1.4.3.

Aldred MJ, Crawford PJ, Roberts E, Thomas NS (1992). Identification of a nonsense mutation in the amelogenin gene (AMELX) in a family with X-linked amelogenesis imperfecta (AIH1). Hum Genet 90:413-416.

Bartel PL, Chien CT, Sternglanz R, Fields S (1993). Using the two-hybrid system to detect protein-protein interactions. In: Cellular interactions in development: a practical approach. Hartley DA, editor. Oxford: Oxford University Press, pp. 153-179.

Bashir MM, Abrams WR, Rosenbloom J (1998). Molecular cloning and characterization of the bovine and human tuftelin genes. Proceedings of the 6th International Symposium on the Composition, Properties and Fundamental Structure of Tooth Enamel. Connect Tissue Res (in press).

Cerny R, Slaby I, Hammarström L, Wurtz T (1996). A novel gene expressed in rat ameloblasts codes for proteins with cell binding domains. J Bone Min Res 11:883-891.

Chevray PM, Nathans D (1992). Protein interaction cloning in yeast: identification of mammalian proteins that react with the leucine zipper of Jun. Proc Natl Acad Sci USA 89:5789. 5793.
Deutsch D, Palmon A, Dafni L, Shenkman A, Sherman J, Fisher LW, et al. (1991a). In: Mechanisms and phylogeny of mineralization in biological systems. Suga S, Nakahara $\mathrm{H}$, editors. Tokyo: Springer-Verlag, pp. 73-77.

Deutsch D, Palmon A, Fisher LW, Kolodny N, Termine JD, Young MF (1991b). Sequencing of bovine enamelin ("tuftelin"), a novel acidic enamel protein. J Biol Chem 266:16021-16028.

Deutsch D, Dafni L, Palmon A, Hekmati M, Young MF, Fisher LW (1997). Enamel mineralization and amelogenesis imperfecta. In: Dental enamel. Chadwick DJ, Cardew G, editors. Ciba Foundation Symposium 205. Chichester: John Wiley and Sons, pp. 135-155.

Doi Y, Eanes ED, Shimokawa H, Termine JD (1984). Inhibition of seeded growth of enamel apatite crystals by amelogenin and enamelin proteins in vitro. J Dent Res 63:98-105.

Fincham AG, Moradian-Oldak J, Simmer JP, Sarte P, Lau EC, Diekwisch T, et al. (1994). Self-assembly of a recombinant amelogenin protein generates supramolecular structures. I Struct Biol 112:103-109.

Fincham AG, Moradian-Oldak J, Diekwisch TG, Lyaruu DM, Wright JT, Bringas P Jr, et al. (1995). Evidence for amelogenin "nanospheres" as functional components of secretory-stage enamel matrix. J Struct Biol 115:50-59.

Fields S, Song O (1989). A novel genetic system to detect protein-protein interactions. Nature 340:245-246.

Fong CD, Slaby I, Hammarström L (1996). Amelin: an enamel related protein, transcribed in the cells of epithelial root sheath. J Bone Min Res 11:892-898.

Hannon GJ, Beach D (1994). p15INK4B is a potential effector of TGF- $\beta$-induced cell cycle arrest. Nature 371:257-261.

Hu C-C, Fukae M, Uchida T, Qian Q, Zhang $\mathrm{CH}$, Ryu OH, et al. (1997). Sheathlin: cloning, cDNA/polypeptide sequences, and immunolocalization of porcine enamel sheath proteins. J Dent Res 76:648-657.

Krebsbach PH, Lee SK, Matsuki Y, Kozak CA, Yamada KM, Yamada $Y$ (1996). Full-length sequence, localization, and chromosomal mapping of ameloblastin: a novel toothspecific gene. J Biol Chem 271:4431-4435.

Lagerström M, Dahl N, Nakahori Y, Backman B, Landegren U, Pettersson $U$ (1991). A deletion in the amelogenin gene (AMG) causes X-linked amelogenesis imperfecta (AIH1). Genomics 10:971-975.

Lagerström-Fermer M, Nilsson M, Backman B, Salido E, Shapiro L, Pettersson U, et al. (1995). Amelogenin signal peptide mutation: correlation between mutations in the amelogenin gene (AMGX) and manifestations of X-linked amelogenesis imperfecta. Genomics 26:159-162.

Lane DP, Crawford LV (1979). T antigen is bound to a host protein in SV40-transformed cells. Nature 278:261-263.

Lau EC, Mohandas TK, Shapiro LJ, Slavkin HC, Snead ML (1989). Human and mouse amelogenin gene loci are on the sex chromosomes. Genomics 4:162-168.

Lau EC, Simmer JP, Bringas P Jr, Hsu DD, Hu CC, ZeichnerDavid $M$, et al. (1992). Alternative splicing of the mouse amelogenin primary RNA transcript contributes to amelogenin heterogeneity. Biochem Biophys Res Commun 188:1253-1260.

Lee SK, Krebsbach PH, Matsuki Y, Nanci A, Yamada KM, Yamada $Y$ (1996). Ameloblastin expression in rat incisor 
and human tooth germs. Int J Dev Biol 40:1141-1150.

Li B, Fields S (1993). Identification of mutations in p53 that affects its binding to SV40 large T antigen by using the yeast two-hybrid system. FASEB J 7:957-963.

Limeback H, Simic A (1990). Biochemical characterization of stable high molecular-weight aggregates of amelogenins formed during porcine enamel development. Arch Oral Biol 35:459-468.

Lowenstam HA, Weiner S (1989). Biomineralization processes. In: On biomineralization. Chapter 3. New York: Oxford University Press, pp. 25-49.

Lyngstadaas SP, Risnes S, Sproat BS, Thrane PS, Prydz HP (1995). A synthetic, chemically modified ribozyme eliminates amelogenin, the major translation product in developing mouse enamel in vivo. EMBO / 14:5224-5229.

MacDougall M, DuPont BR, Simmons D, Reus B, Krebsbach P, Karrman C, et al. (1997). Ameloblastin gene (AMBN) maps within the critical autosomal dominant amelogenesis imperfecta region at chromosome 4q21. Genomics 41:115-118.

Mann S (1993). Molecular tectonics in biomineralization and biomimetic materials chemistry. Nature (Lond) 365:499-505.

Mechanic GL, Katz EP, Glimcher MJ (1967). The sephadex gel filtration characteristics of the neutral soluble proteins of embryonic bovine enamel. Biochem Biophys Acta 133:97-113.

Moradian-Oldak J, Simmer JP, Lau EC, Sarte PE, Slavkin HC, Fincham AG (1994a). Detection of monodisperse aggregates of a recombinant amelogenin by dynamic light scattering. Biopolymers 34:1339-1347.

Moradian-Oldak J, Simmer JP, Sarte PE, Zeichner-David M, Fincham AG (1994b). Specific cleavage of a recombinant murine amelogenin at the carboxy-terminal region by a proteinase fraction isolated from developing bovine tooth enamel. Arch Oral Biol 39:647-656.

Mosteller RD, Han J, Broek D (1994). Identification of residues of the $\mathrm{H}$-ras protein critical for functional interaction with guanine nucleotide exchange factors. Mol Cell Biol 14:11041112.

Mosteller RD, Park W, Broek D (1995). Analysis of interaction between Ras and CDC25 guanine nucleotide exchange factor using yeast GAL4 two-hybrid system. Meth Enzymol 255:135-148.

Nikiforuk G, Simmons NS (1965). Purification and properties of protein from embryonic bovine enamel. J Dent Res 44:11191122.

Paine ML, Snead ML (1997). Protein interactions during assembly of the enamel organic extracellular matrix. J Bone Min Res 12:221-227.

Paine ML, Deutsch D, Snead ML (1996). Carboxyl-region of tuftelin mediates self-assembly. Connect Tissue Res 35:157161.

Sambrook J, Fritsch EF, Maniatis T (1989). Molecular cloning. A laboratory manual. Cold Spring Harbor, NY: Cold Spring Harbor Laboratory Press, pp. 14.18, 16.66.

Sasaki T, Tagaki M, Yanagisawa T (1997). Structure and function of secretory ameloblasts in enamel formation. In: Dental enamel. Chadwick DJ, Cardew G, editors. Ciba Foundation Symposium 205. Chichester: John Wiley and Sons, pp. 32-53.

Simmer JP, Lau EC, Hu CC, Aoba T, Lacey M, Nelson D, et al. (1994). Isolation and characterization of a mouse amelogenin expressed in Escherichia coli. Calcif Tissue Intl 54:312-319.

Slavkin HC, Boyde A (1974). Cementum: an epithelial secretory product? (abstract) J Dent Res 53:157.

Snead ML (1996). Enamel biology logodaedaly: Getting to the root of the problem, or "Who's on first..."(editorial). J Bone Min Res 11:899-904.

Traub W, Jodaiken A, Weiner S (1984). Diffraction studies of enamel protein-mineral structural relations. In: The chemistry and biology of mineralized tissues. Butler WT, editor. Birmingham, AL: Ebsco Media, pp. 221-226. 